\title{
Significance of mast cell distribution in placental tissue and membranes in spontaneous preterm birth
}

This article was published in the following Dove Press journal:

Journal of Inflammation Research

8 July 2016

Number of times this article has been viewed

\author{
Kate Needham' \\ Mitali Fadia ${ }^{2,3}$ \\ Jane E Dahlstrom ${ }^{2,3}$ \\ Kirsti Harrington ${ }^{2,3}$ \\ Bruce Shadbolt ${ }^{4}$ \\ Stephen J Robson 1,3,5 \\ 'Department of Obstetrics and \\ Gynaecology, Centenary Hospital \\ for Women and Children, Canberra \\ Hospital, Garran, ACT, Australia; \\ ${ }^{2}$ Department of Anatomical Pathology, \\ ACT Pathology, Canberra Hospital, \\ Garran, ACT, Australia; ${ }^{3}$ ANU Medical \\ School, Australian National University, \\ Canberra, ACT, Australia; ${ }^{4}$ Department \\ of Epidemiology and Population \\ Health, Canberra Hospital, Garran, \\ ACT, Australia; ${ }^{5}$ John James Medical \\ Centre, Deakin, ACT, Australia
}

Correspondence: Stephen J Robson Suite 2, John James Medical Centre, I 75 Strickland Crescent, Deakin,

ACT 2600, Australia

Tel +6I 262823033

Fax +6I 262812899

Email stephen.robson@anu.edu.au
Background: Preterm birth is a common cause of adverse neonatal and childhood outcomes, in both the short and long term. Preterm labor is commonly associated with inflammation at the maternal-fetal interface. There is some indirect evidence that mast cells (MCs) might represent a link between hormonal influences and local reactions leading to the onset of labor.

Patients and methods: The placentas and membranes of 51 uncomplicated spontaneous term births were compared to those from 50 spontaneous preterm births. Immunohistochemical staining for MC tryptase was undertaken allowing MC concentration, location, and degranulation status to be determined. Regression modeling was used to compare results.

Results: There were no significant differences in the demographic characteristics of the two cohorts. There were significantly more MCs in the decidua for term births than preterm births $(P=0.03)$. The presence of histological chorioamnionitis did not affect MC concentrations.

Conclusion: Despite evidence suggesting a possible role for MCs in spontaneous preterm birth, this study found that the concentration of decidual MCs was in fact significantly lower in preterm compared to term birth.

Keywords: preterm birth, mast cells, inflammation, cohort study, regression modeling

\section{Introduction}

Despite major advances in perinatal care, the rate of preterm birth increased by $22 \%$ between 1991 and 2011 in Australia, where more than 25,000 babies are now delivered preterm each year. ${ }^{1}$ Preterm birth is well recognized as a major cause of adverse neonatal and childhood outcomes, affecting not only survival in the short term but also longer term quality of life for children. ${ }^{2}$ The more remote from term a child is born, the greater the burden of morbidity and mortality, ${ }^{3}$ but even late preterm birth (from 34 to 36 weeks) has the potential for adverse consequences. ${ }^{4}$ In addition to the direct health effects on children, preterm birth imposes emotional and social strains on a family and the care of children born preterm is very expensive.

Established preterm labor is difficult to treat, and the use of tocolytic agents is associated with a delay of only 1 or 2 days before birth. ${ }^{5}$ Fortunately, even an additional 24 hours allows time for the use of steroids to reduce neonatal respiratory morbidity, safe transfer of mothers to hospitals that can provide suitable care for the preterm neonate, and the use of magnesium sulfate for neuroprotection in very preterm pregnancies.

Studies suggest that preterm labor in women who do not have underlying risk factors (such as multiple pregnancy or cervical shortening) is commonly associated with inflammatory cytokines in both the cervicovaginal fluid and amniotic fluid, but not 
necessarily peripheral blood, suggesting that inflammation at the maternal-fetal interface might play an important role. ${ }^{6,7}$ Unfortunately, preventive strategies for inflammatory causes of preterm birth have not been particularly successful.

Some evidence has arisen suggesting that mast cells (MCs) might represent a link between hormonal influences and local reactions that lead to the onset of labor. MCs are plentiful in the reproductive tract, and their concentration is increased in inflammatory conditions of the cervix. ${ }^{8}$ A study of decidual tissue in spontaneous human early pregnancy loss reported "a dramatic increase in the number of $\mathrm{MCs}$ " compared to normal pregnancy. ${ }^{9}$ In rat models, MC degranulation was "prominent" after antigestagen treatment, and MC-stabilizing agents inhibited the antigestagen-induced cervical ripening. ${ }^{10} \mathrm{MCs}$ express estrogen receptors and their responsiveness to degranulating agents appears to increase with higher environmental estrogen concentrations. ${ }^{11}$ Estradiol itself has been shown to stimulate MC degranulation and this is blocked by tamoxifen, suggesting that estradiol-induced MC degranulation could result from receptor activation. ${ }^{11}$ Progesterone appears to inhibit $\mathrm{MC}$ migration and to downregulate receptor expression on the MC surface, ${ }^{12}$ and progesterone also appears to inhibit histamine secretion. ${ }^{13}$

We have not been able to identify previous studies of MCs in the decidua and membranes of women with preterm labor, and aimed to determine whether there was an increased number, or distribution pattern of MCs in these tissues in women with a spontaneous preterm birth compared to those who labored spontaneously at term.

\section{Patients and methods}

Prospective ethics approval for this study was obtained from the ACT Health Human Research Ethics Committee (EthLR11.085). This study did not require patient consent following formal Ethics Committee consideration, as the samples to be used were collected for routine diagnosis and subsequently stored, and were then retrieved for diagnostic research that was not envisaged at the time of collection (Exemption 3, Category 3, of the ACT Health Human Research Ethics Committee Guidelines). The study group comprised 51 women who had an uncomplicated spontaneous term birth ( $\geq 37$ weeks gestation), and 50 women with a spontaneous pre term birth ( $\leq 34$ weeks gestation). Samples from the placenta disc with membranes were obtained using routine laboratory methods. Sections from the paracentral placental block that included the fetal membranes and decidua were examined. The tissues were fixed in $10 \%$ neutral buffered formalin before processing using standard laboratory methods.
Immunohistochemistry assessment was performed on the Leica Bond Automated System (Vision BioSystems, Leica, Bannockburn, IL, USA) using a standard protocol. Briefly, $4 \mu \mathrm{m}$ thick sections were cut and dried in an oven at $60^{\circ} \mathrm{C}$ for 1 hour. Antigen sites were unmasked by heat treatment for 20 minutes using the Bond Epitope Retrieval Solution 2 from Leica Microsystems (Sydney, NSW, Australia), pH 8.9-9.1. The primary antibody used was a mouse monoclonal MC tryptase (ab2378 1/15,000 dilution; Abcam, Cambridge, UK) with an incubation time of 15 minutes. The detection kit used was the Leica Bond Polymer Refine Detection Kit (a polymeric horseradish peroxidase [HRP]-linker antibody conjugate system) from Leica Microsystems. All sections were counterstained with hematoxylin to allow visualization of the nuclei, coverslipped, and viewed. Known positive and negative controls for each antibody were used.

The number of MCs was determined across ten high-power fields (magnification 40×, Olympus microscope) within both the decidua and membranes for each subject. MCs were assessed for degranulation status and location within the tissues (Figure 1). Two independent pathologists (MF and JD) were responsible for the assessment, and were blinded to the patient cohort at the time of assessment.

In addition to descriptive statistics, generalized linear models were used to test the association between gestation (preterm or term) and the concentration of MCs in the decidua, and the number of MCs in the chorion. A Poisson log-linear model was used in the regressions. A probability of $<0.05$ was considered significant on two-sided $\chi^{2}$ tests. SPSS version 22.0 was the statistical package used.

\section{Results}

All births were vaginal, and maternal characteristics of the study groups are presented in Table 1. Based on the

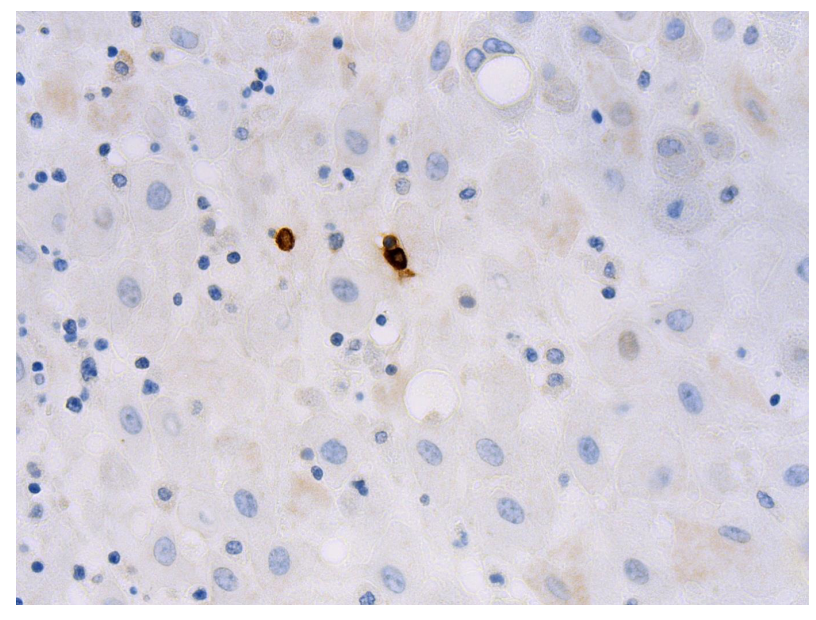

Figure I Photomicrograph showing mast cells (stained brown) within the decidua (mast cell tryptase immunohistochemistry, original magnification $\times 400$ ). 
Table I Demographics of the study groups

\begin{tabular}{|c|c|c|c|c|c|}
\hline & Preterm $(n=50)$ & Term $(n=51)$ & OR & $95 \% \mathrm{Cl}$ & $P$-value \\
\hline Mean maternal age (years) & 27.5 & 28.9 & - & - & - \\
\hline Mean gestational age (weeks) & 27.3 & 39.5 & - & - & - \\
\hline \multicolumn{6}{|l|}{ Fetal factors } \\
\hline Twins & $\mathrm{I}(2 \%)$ & 0 & - & - & - \\
\hline Growth restriction & $3(6 \%)$ & $2(3.92 \%)$ & 1.56 & $0.2,14.1$ & 0.68 \\
\hline Chromosomal abnormality & $2(4 \%)$ & 0 & - & - & - \\
\hline \multicolumn{6}{|l|}{ Maternal comorbidity } \\
\hline Pre-eclampsia & $6(12 \%)$ & $3(5.88 \%)$ & 2.2 & $0.45,11.8$ & 0.32 \\
\hline Diabetes & 0 & $4(7.84 \%)$ & - & - & - \\
\hline Prolonged ruptured membranes $>18$ hours & $7(14 \%)$ & $13(25.49 \%)$ & 0.48 & $0.15,1.45$ & 0.21 \\
\hline Placenta previa & $2(4 \%)$ & 0 & - & - & - \\
\hline Antepartum hemorrhage & $4(8 \%)$ & $2(3.92 \%)$ & 2.1 & $0.31,17.7$ & 0.44 \\
\hline \multirow[t]{2}{*}{ Placental abruption } & 0 & 0 & - & - & - \\
\hline & $\mathrm{I}(2 \%)$ & $\mathrm{I}(1.96 \%)$ & 1.02 & $0.03,38.6$ & 1.0 \\
\hline \multicolumn{6}{|l|}{ Placental pathology } \\
\hline Chorioamnionitis & II (22\%) & $9(17.65 \%)$ & 1.32 & $0.45,3.9$ & 0.63 \\
\hline Retroplacental hemorrhage & $\mathrm{I}(2 \%)$ & 0 & - & - & - \\
\hline Ischemia/advanced maturation & $3(6 \%)$ & 0 & - & - & - \\
\hline Vasculitis & I (2\%) & 0 & - & - & - \\
\hline Villitis & I (2\%) & I (I.96\%) & 1.02 & $0.03,38.6$ & 1.0 \\
\hline
\end{tabular}

Note: -, Analysis was not performed.

Abbreviations: $\mathrm{OR}$, odds ratio; $\mathrm{Cl}$, confidence interval.

generalized linear models, there were significantly more MCs in the decidua for term births than preterm births (Table 2 and Figure 2, $P=0.03$ ). The distribution of MCs according to gestational age is presented in Table 3. There was a scattered distribution of the MCs in the decidua with no obvious concentration around blood vessels. In the membranes there was a higher concentration of MCs in the preterm samples than term samples; however, the association did not reach statistical significance (Table 2 and Figure 2, $P=0.06$ ). The number of MCs was not related to the presence or absence of chorioamnionitis in the placental membranes. While in a few placentas the MCs were noted to be degranulating, there was no difference between preterm and term births.

\section{Discussion}

The aim of this study was to determine whether there were differences in the numbers and distribution of MCs in the membranes and decidua of women, who had a spontaneous preterm birth compared to women delivering at term. The results showed a statistically significant difference in the

Table 2 Estimated marginal mean number of mast cells per microscopic field in decidua $(95 \% \mathrm{Cl})$ and membranes $(95 \% \mathrm{Cl})$ of placentas for preterm vs term babies

\begin{tabular}{|c|c|c|c|c|}
\hline $\begin{array}{l}\text { Gestational } \\
\text { status }\end{array}$ & Decidua & $P$-value & Membranes & $P$-value \\
\hline Preterm $(n=50)$ & $9.12(8.32,10.0)$ & 0.03 & $8.15(7.38,8.99)$ & 0.06 \\
\hline Term $(n=5 I)$ & $10.47(9.62,11.4)$ & & $7.12(6.42,7.90)$ & \\
\hline
\end{tabular}

Abbreviation: $\mathrm{Cl}$, confidence interval. concentration of MCs in the decidua between spontaneous term and preterm birth. However, the association was the opposite of that we had hypothesized, with a decrease in the concentration of MCs in the decidua in preterm births. The difference was subtle, and it is unclear as to whether this represents a clinically significant difference. It is possible that the $\mathrm{MC}$ numbers in the decidua are related simply to gestational age and might not have a role in preterm labor in women with no known underlying risk factors. It is difficult to know whether the differences in the number of MCs between the two groups represents a clinically important difference, or whether such influences as the administration of steroids for fetal lung ripening in the preterm group might have an effect.

Studies in humans suggest that MC numbers increase in pregnancy. ${ }^{14-16}$ Studies in mice have shown that degranulation occurs during birth, and histamine concentrations within MCs reach a peak toward the end of pregnancy, then

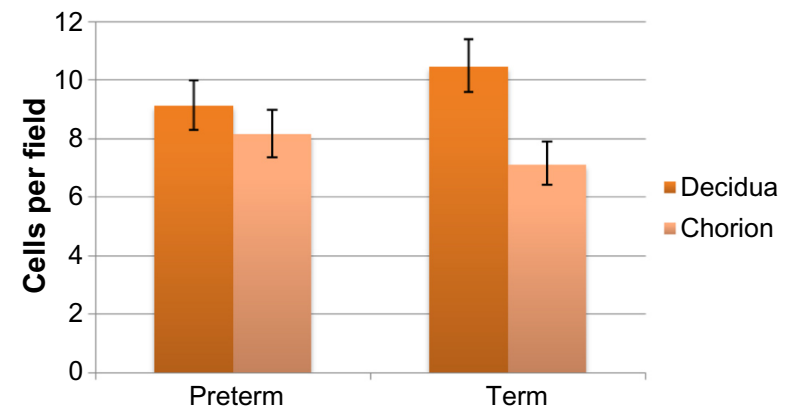

Figure 2 Estimated marginal mean number of mast cell per microscopic field in term placentas versus preterm placentas. 
Table 3 Mean mast cells counts per microscopic field in decidua and chorion, according to gestational age

\begin{tabular}{llll}
\hline $\begin{array}{l}\text { Gestational } \\
\text { age (weeks) }\end{array}$ & $\begin{array}{l}\text { Number of } \\
\text { placentas }\end{array}$ & $\begin{array}{l}\text { Mean count } \\
\text { decidua }\end{array}$ & $\begin{array}{l}\text { Mean count } \\
\text { chorion }\end{array}$ \\
\hline 15 & 1 & Not enough decidua & $\mathrm{I}$ \\
20 & 2 & 4 & $\mathrm{I}$ \\
21 & 1 & 8 & 10 \\
22 & 3 & 5 & 14.3 \\
23 & 3 & 10.7 & 6 \\
24 & 3 & 7.3 & 8.6 \\
25 & 2 & 14.5 & 4 \\
26 & 6 & 12.8 & 4.6 \\
27 & 2 & 5 & 18 \\
28 & 7 & 9 & 9.4 \\
30 & 5 & 11.8 & 10.4 \\
31 & 2 & 16 & 12 \\
32 & 2 & 7 & 9.5 \\
33 & 7 & 18.6 & 7.3 \\
34 & 4 & 7.3 & 6.8 \\
\hline
\end{tabular}

return to normal after delivery. ${ }^{17}$ Studies have shown that patients using inhaled corticosteroids displayed significantly lower numbers of MCs within their epithelium and smooth muscle compared to those not treated with inhaled corticosteroids. ${ }^{18}$

MCs are distributed in areas with exposure to the external environment such as airways, the skin, and mucosal surfaces. However, MCs are also found adjacent to myometrial muscle cells. ${ }^{14-16}$ MCs display tissue-specific phenotypes with different inflammatory mediator content and patterns of receptor expression. ${ }^{19,20}$ Human myometrial MCs seem to have characteristics more typical of airway MCs than those in the skin and mucosal surfaces. ${ }^{21}$ Although present in the myometrium, MCs are thought to be scarce in the endometrium and no cyclic differences in the overall distribution or density of MCs have been described, although there may be differences in granule content of endometrial MCs premenstrually, suggesting prior activation. ${ }^{22}$

Possible confounders to this study include the heterogeneity of the maternal comorbidities in the study groups. There were more women with pre-eclampsia in the preterm group and more women with prolonged rupture of membranes in the term group, although this did not translate into significant differences in placental histopathology. There have been few studies of MCs in the human placenta or decidua in relation to various maternal comorbidities. One small study of placental MC distribution in women at term, comparing the placentas of pre-eclamptic women with normal controls, revealed an increased $\mathrm{MC}$ density in the pre-eclamptic group leading the authors to suggest that MCs might play a role in the disease. ${ }^{23}$
The inflammatory cell influx to the myometrium and endometrium associated with labor coincides with upregulation of several mediators including interleukin 8 (IL-8), all of which are ligands for receptors (such as CXCR1 and others) found on MCs. ${ }^{24,25}$ Inflammatory mediators released by MCs are also known to play a role in several labor-related biological processes including stimulation of smooth muscle cell contraction and promotion of angiogenesis. ${ }^{26}$ There is evidence that MC degranulation products contribute to both cervical angiogenesis in pregnancy and to cervical ripening. ${ }^{27}$ In vitro studies have reported that compounds causing $\mathrm{MC}$ degranulation can induce myometrial contraction, and that pretreatment with MC-stabilizing agents diminishes this effect. ${ }^{28}$ Histamine induces myometrial cell contraction in vitro, both through a direct effect on the $\mathrm{H}_{1}$ receptor ${ }^{16,29}$ and indirectly by inducing prostaglandin production, including prostaglandin $\mathrm{F}_{2 \alpha}$ secretion from decidual cells. ${ }^{30} \mathrm{~A}$ number of prostaglandins including $\mathrm{E}_{2}$ and $\mathrm{F}_{2 \alpha}$ can be directly secreted by $\mathrm{MCs} .{ }^{31,32}$ Of note, in this study the rate of chorioamnionitis between the two groups was similar, making it unlikely to be an explanation for the difference in concentration of MCs between the two groups.

Serotonin secreted by MCs has uterotonic properties ${ }^{33}$ and oxytocin has been shown to inhibit serotonin uptake by uterine MCs, an effect that might increase its local bioavailability during labor. ${ }^{34}$ Release of MC tryptase is also known to stimulate production and release of matrix metalloproteinases from endometrial stromal cells, and increases in endometrial matrix metalloproteinase expression have been observed in the perimenstrual phase..$^{35,36}$

\section{Conclusion}

Despite a body of indirect evidence pointing to a possible role for MCs in spontaneous preterm birth, this study found that the concentration of MCs was significantly lower in the decidua in preterm compared to term birth. Whether this might represent an effect of gestation, or may even be related to administration of steroids, remains indeterminate.

\section{Acknowledgment}

We wish to thank the Staff in the Department of Anatomical Pathology, ACT Pathology who initially processed and reported on the placentas in this study.

\section{Disclosure}

The authors report no conflicts of interest in this work. 


\section{References}

1. Li Z, Zeki R, Hilder L, Sullivan EA. Australia's Mothers and Babies 2011. Perinatal Statistics Series No 28, Cat No PER 59. Canberra, Australia: AIHW National Perinatal Epidemiology and Statistics Unit; 2013.

2. Saigal S, Doyle LW. An overview of mortality and sequelae of preterm birth from infancy to adulthood. Lancet. 2008;371:261-269.

3. Moser K, Macfarlane A, Chow YH, Hilder L, Dattani N. Introducing new data on gestation specific infant mortality among babies born in 2005 in England and Wales. Health Stat Q. 2007;35:13-27.

4. Kramer MS, Demissie K, Yang H, et al. The contribution of mild and moderate preterm birth to infant mortality. JAMA. 2000;284: 843-849.

5. Gyetvai K, Hannah ME, Hodnett ED, Ohlsson A. Tocolytics for preterm labor: a systematic review. Obstet Gynecol. 1999;94:869-877.

6. Wei S, Fraser W, Luo Z. Inflammatory cytokines and spontaneous preterm birth in asymptomatic women: a systematic review. Obstet Gynecol. 2010;116:393-401.

7. Romero R, Espinoza J, Goncalves L, et al. The role of inflammation and infection in preterm birth. Semin Reprod Med. 2007;25:21-39.

8. Naik R, Pai M, Poornima Baliga B, et al. Mast cell profile in uterine cervix. Indian J Pathol Microbiol. 2004;47:178-180.

9. Marx L, Arck P, Kieslich C, et al. Decidual mast cells might be involved in the onset of human first-trimester abortion. Am J Reprod Immunol. 1999;41:34-40.

10. Spanggaard H, Knudsen U, Uldbjerg N, et al. Mast cells in cervical ripening - an immunohistochemical and biomechanical study in rats. Eur J Obstet Gynecol Reprod Biol. 1997;73:91-97.

11. Zaitsu M, Narita S, Lambert KC, et al. Estradiol activates mast cells via a non-genomic estrogen receptor-alpha and calcium influx. Mol Immunol. 2007;44:1977-1985.

12. Belot M, Abdennebi-Najar L, Gaudin F, et al. Progesterone reduces the migration of mast cells toward the chemokine stromal cell-derived factor-1/CXCL12 with an accompanying decrease in CXCR4 receptors. Am J Physiol Endocrinol Metab. 2007;292:E1410-E1417.

13. Vasiadi M, Kempuraj D, Boucher W, et al. Progesterone inhibits mast cell secretion. Int J Immunopathol Pharmacol. 2006;19:787-794.

14. Mori A, Zhai Y, Toki T, et al. Distribution and heterogeneity of mast cells in the human uterus. Hum Reprod. 1997;12:368-372.

15. Mori A, Nakayama K, Suzuki J, et al. Analysis of stem cell factor for mast cell proliferation in the human myometrium. Mol Hum Reprod. 1997;3:411-418

16. Garfield R, Irani A, Schwartz L, et al. Structural and functional comparison of mast cells in the pregnant versus non-pregnant human uterus. Am J Obstet Gynecol. 2006;194:261-267.

17. Padilla L, Reinicke K, Montesino H, et al. Histamine content and mast cell distribution in mouse uterus: the effect of sexual hormones, gestation and labor. Cell Mol Biol. 1990;36:93-100.

18. James A, Gyllfors P, Henriksson E, et al. Corticosteroid treatment selectively decreased mast cells in smooth muscle and epithelium of asthmatic bronchi. Allergy. 2012;67(7):958-961.

19. Kitamura Y. Heterogeneity of mast cells and phenotypic change between subpopulations. Annu Rev Immunol. 1989;7:59-76.
20. Bradding P. Human lung mast cell heterogeneity. Thorax. 2009;64: 278-280.

21. Massey W, Guo C, Dvorak A, et al. Human uterine mast cells. Isolation, purification, characterization, ultrastructure, and pharmacology. J Immunol. 1991;147:1621-1627.

22. Sivridis E, Giatromanolaki A, Agnantis N, Anastasiadis P. Mast cell distribution and density in the normal uterus - metachromatic staining using lectins. Eur J Obstet Gynecol Reprod Biol. 2001;98:109-113.

23. Szewczyk G, Pyzlak M, Klimkiewicz J, et al. Mast cells and histamine: do they influence placental vascular network and development in preeclampsia? Med Inflamm. 2012;2012:1-5.

24. Oliveira S, Lukacs N. Stem cell factor and igE-stimulated murine mast cells produce chemokines (CCL2, CCL17, CCL22) and express chemokine receptors. Inflamm Res. 2001;50:168-174.

25. Brightling C, Kaur D, Berger P, et al. Differential expression of CCR3 and CXCR3 by human lung and bone marrow-derived mast cells: implications for tissue mast cell migration. J Leukoc Biol. 2005;77: 759-766.

26. Norrby K. Mast cells and angiogenesis. APMIS. 2002;110(5):355-371.

27. Sennstrom MK, Brauner A, Lu Y, et al. Interleukin- 8 is a mediator of the final cervical ripening in humans. Eur J Obstet Gynecol Reprod Biol. 1997;74(1):89-92.

28. Bytautiene E, Vedernikov Y, Saade GR, et al. Degranulation of uterine mast cell modifies contractility of isolated myometrium from pregnant women. Am J Obstet Gynecol. 2004;191:1705-1710.

29. Willets J, Taylor A, Shaw H, et al. Selective regulation of $\mathrm{H} 1$ histamine receptor signaling by $\mathrm{G}$ protein-coupled receptor kinase 2 in uterine smooth muscle cells. Mol Endocrinol. 2008;22:1893-1907.

30. Schrey M, Hare A, Ilson S, Walters M. Decidual histamine release and amplification of prostaglandin F2 alpha production by histamine in interleukin-1 beta-primed decidual cells: potential interactive role for inflammatory mediators in uterine function at term. J Clin Endocrinol Metab. 1995;80:648-653.

31. Chock S, Schmauder-Chock E. Synthesis of prostaglandins and eicosanoids by the mast cell secretory granule. Biochem Biophys Res Commun. 1988;156:1308-1315.

32. Kawata R, Reddy S, Wonder B, Herschman H. Prostagladin synthetast 1 and prostaglandin synthetase 2 both participate in activation-induced prostaglandin D2 production in mast cells. J Immunol. 1995;155: 818-825.

33. Rudolph M, Reinicke K, Cruz MA, et al. Distribution of mast cells and the effect of their mediators on contractility in human myometrium. Br J Obstet Gynaecol. 1993;100:1125-1130.

34. Rudolph M, Oviedo C, Vega E, et al. Oxytocin inhibits the uptake of serotonin into uterine mast cells. J Pharmacol Exp Ther. 1998;287: 389-394.

35. Zhang J, Nie G, Jian W, et al. Mast cell regulation of human endometrial matrix metalloproteinases: a mechanism underlying menstruation. Biol Reprod. 1998;59:693-703.

36. Hampton A, Salamonsen L. Expression of messenger ribonucleic acid encoding matrix metalloproteinases and their tissue inhibitors is related to menstruation. J Endocrinol. 1994;141:R1-R3.

Journal of Inflammation Research

\section{Publish your work in this journal}

The Journal of Inflammation Research is an international, peer-reviewed open-access journal that welcomes laboratory and clinical findings on the molecular basis, cell biology and pharmacology of inflammation including original research, reviews, symposium reports, hypothesis formation and commentaries on: acute/chronic inflammation; mediators of inflamma-

tion; cellular processes; molecular mechanisms; pharmacology and novel anti-inflammatory drugs; clinical conditions involving inflammation. The manuscript management system is completely online and includes a very quick and fair peer-review system. Visit http://www.dovepress.com/ testimonials.php to read real quotes from published authors. 